REVISTA DE DERECHO UNED, NÚM. 21, 2017

\title{
LAS CLÁUSULAS SUELO: UN PROBLEMA DE TRANSPARENCIA Y ENTENDIMIENTO ${ }^{1}$
}

\section{FLOOR CLAUSES: A TRANSPARENCY AND UNDERSTANDING PROBLEM}

Francisco María Pérez VÁzQuez

Funcionario del Cuerpo de Administradores Generales de la Junta de Andalucía

Máster EEES UNED Intervención de la Administración en la sociedad

Resumen: El presente trabajo aborda el tema de las cláusulas suelo desde el momento en que su repercusión social lo hace recalar en el Senado hasta la sentencia del Tribunal Supremo, de 25 de marzo de 2015. La síntesis efectuada ha recogido la interpretación realizada por la doctrina científica sobre disposiciones legales vigentes, en particular, la problemática originada por concretas modificaciones legislativas como consecuencia de la transposición de la Directiva 93/13/ CEE al ordenamiento jurídico español. El tratamiento del asunto sería incompleto sin considerar la función y la doctrina vinculante del Tribunal de Justicia de la Unión Europea (TJUE) generada mediante el mecanismo de las cuestiones prejudiciales. El trabajo recoge los pronunciamientos más notorios de nuestros juzgados y audiencias, de cuya meritoria labor conjunta puede afirmarse, sin tacha de exageración, que ha producido el análisis de todo lo discutible, desde el punto de vista formal como material. Con la doctrina del Tribunal Supremo (TS) sobre la transparencia de las cláusulas suelo y la valoración que dicha construcción ha merecido a las voces más autorizadas pondremos fin a esta labor.

${ }^{1}$ Estas páginas han sido extraídas de nuestro Trabajo Fin de Máster «Las cláusulas suelo. Un problema de transparencia y entendimiento». Máster UNED «Intervención de la Administración en la sociedad». Director del Trabajo, Dr. Juan Carlos Menéndez Mato, septiembre de 2016. 
Abstract: The current work deals with the issue of floor clauses from the moment when it reaches the Senate, due to its social repercussions, until the High Court sentence March 25th 2015. The synthesis that has been carried out reflects the interpretation made by the most competent authorities doctrine about the current legal provisions, especially the problems caused by specific legal modifications and as consequence of the transposition of the EC Directive 93/13 to the Spanish legal system. The treatment of this matter would be incomplete if we don't take into account the function and binding doctrine of the European Union Court of Justice, generated by the mechanics of preliminary issues. This work compiles the most remarkable pronouncements of our judges and magistrates whose commendable combined task can be said without exageration to have produced a complete analysis of every arguable matter from the formal point of view as well as from the material one. We will finish this work with the High Court doctrine about the transparency of floor clauses and the assesment that the most authorised voice have made about this.

Palabras clave: cláusulas suelo, cláusulas abusivas, nulidad, retroactividad, transparencia.

Keywords: floor clauses, unfair clauses, nullity, retroactivity, transparency.

Recepción original: 30/06/2017

Aceptación original: 27/10/2017

Sumario: I. El conflicto en las instituciones del Estado. II. Las fuentes jurídicas y el Tribunal de Justicia de la Unión Europea (TJUE). A. Las fuentes jurídicas. La transposición de la Directiva 93/13/CEE al ordenamiento jurídico nacional. B. El Tribunal de Justicia de la Unión Europea. 1. Sentencias del TJUE dictadas en cuestiones prejudiciales planteadas por órganos judiciales españoles. 2. Doctrina del TJUE en la sentencia del Tribunal Supremo (STS) de 9 de mayo de 2013. III. Las cláusulas suelo en las instancias judiciales. IV. El control sobre las cláusulas abusivas que recogen elementos esenciales del contrato. A. El control en la doctrina de autores. B. El control realizado por juzgados y Audiencias Provinciales hasta la STS de 9 de mayo de 2013. La antijuricidad de las cláusulas suelo como cláusulas abusivas. C. El control de los elementos esenciales en la doctrina del Tribunal Supremo. 1. Precedentes inmediatos de la STS de 9 de mayo de 2013 desde la STJUE de 3 de junio de 2010 (Caja Madrid). 2. El control de transparencia en la STS de 9 de mayo de 2013. V. Fallos y efectos. VI. Hacia la consolidación de la doctrina de la transparencia. A. Repercusión de la STS de 9 de mayo de 2013 sobre sentencias posteriores. B. El TS ajusta su doctrina sobre la transparencia. VII. Conclusiones. Postscriptum. 


\section{EL CONFLICTO EN LAS INSTITUCIONES DEL ESTADO}

Como es sabido, el Senado debatió el 23 de septiembre de 2009 la posibilidad de una intervención contra posibles prácticas abusivas de las entidades bancarias en los contratos de préstamo hipotecario. El Pleno aprobó una moción por la que instaba al Gobierno a actuar contra aquéllas ${ }^{1}$ y a solicitar del Banco de España, con carácter previo, la elaboración y remisión de un informe (IBE) sobre dos puntos: la existencia de cláusulas en los contratos de préstamos hipotecarios que limitaran los derechos de los usuarios, determinaran «la falta de reciprocidad» o fueran "desproporcionadas», y, en segundo lugar, «establecer la efectiva traslación de los descensos del Euribor a las cuotas de las hipotecas»².

El IBE defendió la legalidad de las citadas cláusulas al hallarse excluidas del control de abusividad (art. 4.2 Directiva 93/13/CEE), la voluntad del legislador de dejarlas al juego de la autonomía de la voluntad de las partes y las reglas del mercado, y su validez siempre que resultaran de un acuerdo contractual expreso entre las partes o fueran libremente consentidas por los prestatarios, hallándose amparadas por el Derecho bancario ${ }^{3}$. También reconoció que las cláusulas techo no protegían efectivamente a los clientes ante el riesgo de subida de los tipos de interés (IBE párr. 3.3). No obstante, el informe exoneró de responsabilidad a los bancos, aventurando un impacto negativo en sus cuentas si las citadas cláusulas fueran eliminadas en los préstamos hipotecarios ${ }^{4}$. El IBE fue decisivo para que el Senado, el 21 de julio de 2010, rechazara en ajustada votación la modificación de la Ley 26/1984, de 19 de julio, General para la Defensa de los Consumidores y Usuarios (LGDCU) ${ }^{5}$.

En octubre de 2010, la Asociación de Usuarios de Bancos, Cajas y Seguros (o de Impositores de Bancos y Cajas de ahorros, ADICAE) emitió un informe jurídico-económico respondiendo al IBE en el que, enfrentando una visión real de los hechos con la abstracción porcentual empleada por el BE, consideraba abusivas las cláusulas suelo en base a la infracción de diversos preceptos y principios jurídicos, así como de la Directiva 93/13/CEE. ADICAE sostenía que las cláusulas

${ }^{1}$ BO Cortes Generales, Diario de sesiones del Senado, núm. 52, de 23 de septiembre de 2009, pág. 2394.

${ }^{2}$ BO Cortes Generales, Senado, núm. 457, de 7 de mayo de 2010, pág. 12, párrafo 1. Antecedentes.

${ }^{3}$ Orden Ministerial sobre transparencia de las condiciones financieras de los préstamos hipotecarios, BOE núm. 112, de 11 de mayo de 1994.

${ }^{4}$ BO Cortes Generales, Senado, núm. 457, de 7 de mayo de 2010, pág. 23.

${ }^{5}$ BO Cortes Generales, Diario de Sesiones del Senado, núm. 89, de 21 de julio de 2010, pág. 4864. 
suelo han supuesto que en 2009 los bancos y las cajas ingresaran entre 3.300 y casi 7.000 millones de euros más de lo que correspondía (pág. 19), pues dichas cláusulas modifican el coste del préstamo en perjuicio del consumidor (pág. 25) .

Trasladado el conflicto al Defensor del Pueblo, realizó un exhaustivo análisis sobre la regulación de nuestro sistema jurídico hipotecario y procesal. En numerosos préstamos hipotecarios apreció falta de reciprocidad evidente entre las partes en la aplicación de las cláusulas suelo, pero entendió el problema no como de falta de información, obligación ya dispuesta por la normativa vigente, «sino de aplicación efectiva de las medidas aprobadas con el fin de garantizar que este tipo de cláusulas, oscuras y complejas para la mayor parte de los ciudadanos, sean explicadas de manera comprensible» (pág. 67). Criticó abiertamente la labor del BE recomendando, entre otras medidas, reforzar la independencia del Servicio de Reclamaciones del BE (4.1), mejorar la transparencia (4.2.1) y desarrollar la obligación de concesión responsable de crédito conociendo la solvencia del cliente (4.2.3) ${ }^{7}$.

\section{LAS FUENTES JURÍDICAS Y EL TRIBUNAL DE JUSTICIA DE LA UNIÓN EUROPEA (TJUE)}

\section{A. Las fuentes jurídicas. La transposición de la Directiva 93/13/CEE al ordenamiento jurídico nacional}

La LGDCU pretendió dar cumplimiento al principio constitucional de defensa de los consumidores y usuarios (art. $51 \mathrm{CE}$ ) estableciendo los requisitos de buena fe y justo equilibrio de las contraprestaciones para las cláusulas, condiciones o estipulaciones generales de los contratos y considerando abusivas las que perjudicaban de

${ }^{6}$ Entre los muchos argumentos del informe dejamos señalados los siguientes: los suelos se han establecido garantizando su aplicación en perjuicio del consumidor, mientras que los techos se han fijado en niveles inalcanzables, más de un $250 \%$ por encima del máximo histórico del Euribor (pág. 12). Las entidades conocían que se iba a producir una bajada de tipos del Euribor y su dilatado estancamiento temporal (pág. 13). Fuente www.afectadosclausulasuelo.org/archivos/Informe. Consultada el 11/4/16. Doc. pdf.

${ }^{7}$ Informe de 22 de enero de 2012 denominado «Crisis económica y deudores hipotecarios: Actuaciones y propuestas del Defensor del Pueblo». El párr. 3, referido a las Actuaciones del Defensor del Pueblo dedica el apartado 3.3 a las hipotecas con cláusulas suelo. Para el Defensor la falta de neutralidad del Banco de España ante las reclamaciones y los nocivos efectos de desprotección de la clientela justificaban la desconfianza en el sistema bancario y nada favorecía su funcionamiento. Fuente https://www.defensordelpueblo.es/crisis-economica-y-deudores-hipotecarios. 
manera desproporcionada o no equitativa al consumidor, o comportaban en el contrato una posición de desequilibrio entre los derechos y obligaciones de las partes en perjuicio de los consumidores o usuarios $^{8}$.

Casi una década más tarde nacía la Directiva 93/13/CEE del Consejo $^{9}$, de 5 de abril de 1993, sobre las cláusulas abusivas en los contratos celebrados con los consumidores, con el objetivo proteger a los consumidores de los Estados miembros frente a los abusos del mercado. Entre sus preceptos y principios destacan el de eliminación de las cláusulas abusivas de los contratos de bienes y servicios (Considerando VI), la garantía de que dichas cláusulas no obligarán al consumidor si a pesar de las medidas adoptadas por los Estados subsistieran en los contratos (Considerandos IV y XXI, art. 6), y que el carácter abusivo de las cláusulas no debe referirse a las que describan el objeto principal del contrato ni a la relación calidad precio de la mercancía o de la prestación (Considerando XIX), siempre que dichas cláusulas sean redactadas de manera clara y comprensible (art. 4.2). La Directiva finaliza con un anexo indicativo de cláusulas abusivas (art. 3.3).

La necesidad de trasladar los preceptos de la citada Directiva al ordenamiento jurídico español fue atendida por el legislador a través de la Disposición adicional primera de la Ley 7/1998, de 13 de abril, sobre condiciones generales de la contratación (LCGC). La citada Disposición adicional, en su punto 2 , dio nueva redacción al artículo 10 coincidente con la utilizada por el legislador comunitario en el artículo 3.1 de la Directiva, de manera que, con referencia a las cláusulas, condiciones o estipulaciones, sustituyó el requisito original del justo equilibrio de las contraprestaciones por el «justo equilibrio entre los derechos y obligaciones de las partes» (art. 10.1.c). El punto 3 de la citada Disposición añadió el artículo 10 bis sobre cláusulas abusivas, cuyo punto 1 hacía lo propio en su concepto añadiendo la contravención de la buena fe y que había de ser importante el desequilibrio en los derechos y obligaciones de las partes. Por fin, la LCGC añadía a la LGDCU una Disposición adicional primera que realizó una clasificación de las cláusulas consideradas abusivas (punto 6 de la Disposición adicional primera LCGC) ${ }^{10}$.

${ }^{8}$ Artículo 10.1. c) y punto 3 de esta letra en la redacción original de la Ley 26/1984.

${ }^{9}$ DOUE núm. L 95/29, de 21 de abril de 1993.

${ }^{10}$ Desaparecía de la norma la idea de perjuicio desproporcionado o no equitativo, aunque se mantenía que la insubsanable situación no equitativa de las partes a tenor de las cláusulas subsistentes era bastante para declarar la ineficacia del contrato (art. 10 bis. 2). 
Para ciertos autores esta modificación fue transcendental porque incorporó la distinción entre el contenido económico y el contenido normativo del contrato y modificó el objeto sometido a control, de manera que a partir de entonces, lo único sometido al control judicial del contenido es el equilibrio jurídico del contrato y no el precio o la relación calidad-precio de las prestaciones ${ }^{11}$. Sin embargo, se ha objetado que pese a los esfuerzos doctrinales y jurisprudenciales y a las auténticas filigranas conceptuales propuestas, no ha llegado a establecerse con carácter convincente una línea firme que delimite el contenido económico del contrato de su contenido normativo, por lo que en la fórmula desequilibrio importante en los derechos y obligaciones caben el desequilibrio jurídico y el económico ${ }^{12}$.

Las cláusulas suelo han reactivado esta controversia doctrinal. Cualquier planteamiento jurídico que pretenda dar respuesta al problema se enfrenta de inicio con una acción legislativa incompleta, porque el legislador no llevó a la LCGC la previsión establecida en el artículo 4.2 de la Directiva. Este silencio dividió a la doctrina. Unos autores defendieron dicho control económico en los contratos entre empresarios y consumidores aduciendo que, ante la ausencia de normas en la LCGC que expresamente lo excluyera, se ha de entender que el legislador optó conscientemente por el control judicial de la relación calidad-precio. Considerando también el principio general de protección del consumidor, ello significaría un aumento del grado de protección que no contradice la Directiva 93/13/CEE ni el Derecho español $^{13}$. Además, el carácter de mínimos de la Directiva permite a los tribunales examinar la abusividad de todo tipo de cláusulas, con independencia de su incidencia en el contenido del contrato ${ }^{14}$.

Por otro lado, la posición que se ha reconocido mayoritaria ha sido contraria a un control judicial de precios abusivos en los contratos celebrados entre consumidores y empresarios. Quizá la razón más grave ofrecida por la doctrina haya sido la supuesta inconstitucionalidad de tal facultad por atentar contra los artículos 10.1 y 38 de la

${ }^{11}$ Cfr. CÁmara Lapuente, S. El control de las cláusulas abusivas sobre elementos esenciales del contrato. ¿Incorrecta transposición, opción legal legítima o mentís jurisprudencial?, edición 1. ${ }^{a}$, Ed. Thomson Aranzadi, Navarra, 2006, pág. 98.

${ }^{12}$ Cfr. Pertíñez Vílchez, F. «Falta de transparencia y carácter abusivo de la cláusula suelo en los contratos de préstamo hipotecario", Indret, Revista para el análisis del derecho, Barcelona, Julio, 2013, págs. 21 y 24.

${ }^{13}$ Cfr. Duque Domínguez, F., «Las cláusulas abusivas en los contratos de consumo», en Nieto Carol, U. (director) y otros, Condiciones generales de la contratación y cláusulas abusivas, edición 1. a, Ed. Lex Nova, Valladolid, 2000, pág. 486.

${ }^{14}$ Cfr. Llamas Pombo, E, "La nulidad de las cláusulas suelo», Ars Iuris Salmanticensis, Tribuna de actualidad, Vol. 1, 11-17, Diciembre 2013, pág. 13. 
Constitución ${ }^{15}$. La libertad contractual y la determinación del contenido del contrato, se afirma, no puede quedar en manos de los jueces en base a una cláusula general (art. 10 bis. 1 LGDCU). También se opone que un principio de interpretación conforme a la Directiva, ante el silencio del legislador, debe entenderse en el sentido de que no se controlan los elementos esenciales en los contratos con los consumidores ${ }^{16}$; nuestra Ley no ha establecido el control de precios en ningún precepto, por lo que es inviable un control de contenido referido a los elementos esenciales del contrato; que el control de contenido no es un control de precios ni del equilibrio de las prestaciones, no obstante reconocerse que no es constitucionalmente imposible establecerlo en ámbitos determinados y por razones especiales ${ }^{17}$, y, por poner término, que el sistema de economía social de mercado de nuestra Constitución económica atribuye al mercado, por medio de la competencia, la fijación de los precios y las ofertas de bienes y servicios ${ }^{18}$.

En la doctrina también se ha censurado el hecho de que se deposite en la competencia mercantil la protección de los consumidores ${ }^{19}$, y cierta falta de comprensión de los bienes constitucionales que entran en tensión, debido quizá a la influencia de tratadistas de Derecho Mercantil que conectan la protección de consumidores y usuarios con otros principios y derechos constitucionales como la libertad de empresa y la autonomía privada (art. 53.1 y art. 33.1 CE) ${ }^{20}$.

${ }^{15}$ Cfr. Alfaro Águila-Real, J. «Comentario al artículo 1», en Alfaro Águila-Real J. (coordinador) y otros, Comentarios a la Ley sobre condiciones generales de la contratación, Ed. Civitas, Madrid, 2002 cit., pág. 131.

${ }^{16}$ Cfr. Arroyo Martínez I. y Míouel Rodríguez, J (coordinadores), Comentarios a la Ley sobre Condiciones Generales de la Contratación», Ed. Tecnos, Madrid, 1999. ARROYO recuerda que en los trabajos preparatorios de la Directiva se incluía el control de los elementos esenciales, pero la oposición alemana propició la modificación del criterio, págs. 30-31.

${ }^{17}$ Cfr. Míquel Rodríguez, J. M., "Comentario a la Disposición adicional 1. a , 3 » en Alfaro Águila-Real J. (coordinador) y otros, Comentarios a la Ley sobre condiciones generales..., cit. págs. 894 y 910.

${ }^{18} \mathrm{Cfr}$. PAgador LóPez, J. Condiciones generales y cláusulas contractuales predispuestas. La Ley de condiciones generales de la contratación, Marcial Pons, Madrid, 1999, págs. 282 a 284. Las págs. 281 y 282 ofrecen su largo debate con MARTín LóPEZ, de posición contraria, y más breve con BERCOVITZ.

${ }^{19}$ Cfr. Díaz Alabart, S., "Pacta sunt servanda e intervención judicial en el equilibrio de los contratos: reflexión sobre la incidencia de la Ley de condiciones generales de los contratos», en AAVV, Condiciones generales de la contratación y cláusulas abusivas, director Nieto Carol, U., Lex Nova, Valladolid, 2000, pág. 58. Cfr. también en Duque Domínguez, F., "Las cláusulas abusivas en los contratos de consumo», cit., pág. 485.

${ }^{20}$ Cfr. Lasarte Álvarez, C., Manual sobre protección de consumidores y usuarios, ed. Sexta, Ed. Dykinson, Madrid, 2014. Suma a su opinión la de García Cantero, García Cruz y Martínez de AguirRe, págs. 28 a 30. 
Sin intención de preterir a ningún autor, lo que interesa resaltar es la vigencia del problema si se sostiene que la transposición de la Directiva en el precepto indicado continúa siendo una asignatura pendiente para el legislador ${ }^{21}$.

Más cercano a nuestro días, el vigente Decreto Legislativo 1/2007, de 16 de noviembre, por el que se aprueba el Texto Refundido de la Ley General para la Defensa de los Consumidores y Usuarios y otras leyes complementarias (TRLGDCU), regulará las acciones de cesación (Capítulo I del Título V, Libro Primero) y el régimen de las condiciones generales y las cláusulas abusivas (Capítulos I -cláusulas contractuales no negociadas individualmente-, y II -cláusulas abusivas-, del Título II, Libro Segundo), conforme a las previsiones contenidas en la LGDCU.

\section{B. El Tribunal de Justicia de la Unión Europea}

De acuerdo con el artículo 19.1 del Tratado de Funcionamiento de la Unión Europea (TFUE), el TJUE garantiza el respeto del Derecho Europeo por los Estados miembros y la uniformidad de su interpretación y aplicación por los jueces y tribunales nacionales. El TJUE es por tanto el intérprete supremo y garante del ordenamiento jurídico europeo, función que ejerce de forma indirecta a través de un mecanismo de colaboración judicial denominado cuestión prejudicial de interpretación de los Tratados. La cuestión la inicia un juez o tribunal nacional que, albergando dudas razonables sobre la interpretación del Derecho europeo originario o derivado, pide al TJUE que se pronuncie al ser ello necesario para poder dictar sentencia (art. 267, párrafo segundo TFUE) ${ }^{22}$. Esta facultad se convierte en obligación si las decisiones del órgano jurisdiccional nacional no son susceptibles de ulterior recurso judicial de Derecho interno (art. 267, párrafo tercero TFUE). Por ello resulta indispensable recordar la respuesta dada por el Tribunal a cuestiones prejudiciales planteadas por órganos judiciales españoles y de otros Estados comunitarios que constituyen presupuestos jurídicos de la STS de 9 de mayo de 2013, primera sobre las mencionadas cláusulas.

${ }^{21}$ Cfr. CÁmara Lapuente, S., "Transparencias, desequilibrios e ineficacias en el régimen de las cláusulas abusivas» (un resumen crítico), en El Notario del Siglo XXI, noviembre-diciembre 2015, núm. 64. Fuente informática www.elnotario.es; consulta realizada el día 11/7/16.

${ }^{22}$ Cfr. Bacigalupo Sagesse, M., "El sistema jurisdiccional de la Unión Europea», en Linde Paniagua E. y otros, Principios de Derecho de la Unión Europea. 6. ${ }^{\text {e edición, }}$ Ed. Colex, 2012, págs. 498-499. 
1. Sentencias del TJUE dictadas en cuestiones prejudiciales planteadas por órganos judiciales españoles.

En primer lugar, la STJUE de 3 de junio de 2010 (asunto C-484/08, Caja Madrid) ${ }^{23}$. El Tribunal declaró que los artículos 4.2 y 8 de la Directiva 93/13/CEE «no se oponen a una normativa nacional... que autoriza un control jurisdiccional del carácter abusivo de las cláusulas contractuales que se refieren a la definición del objeto principal del contrato o a la adecuación entre, por una parte, precio y retribución y, por otra, los servicios o bienes que hayan de proporcionarse como contrapartida, aunque estas cláusulas estén redactadas de manera clara y comprensible». Tampoco esa normativa vulneraría los principios comunitarios de libre competencia en una economía de mercado abierta y no falseada (párrs. 1 y 2), porque la Directiva sólo ha realizado una armonización parcial y mínima de las legislaciones nacionales sobre cláusulas abusivas, reconociendo a los Estados miembros la posibilidad de garantizar al consumidor una protección más elevada (párr. 28).

Seguidamente, en la STJUE de 14 de junio de 2012 (asunto C-618/10, Banco Español de Crédito vs. Calderón), el Tribunal interpretó que el artículo 6.1 de la Directiva impone a los jueces nacionales, desde el inicio del proceso, la obligación de dejar sin aplicación la cláusula abusiva, a fin de que ésta no produzca efectos vinculantes para el consumidor ${ }^{24}$. El contrato debía subsistir sin las cláusulas abusivas, en la medida en que fuera jurídicamente posible según el ordenamiento interno (párr. 65). Además, los jueces no tienen facultad para integrar o modificar el contenido contractual, razón por la

${ }^{23}$ La cuestión prejudicial es suscitada por el TS (Auto de 20 de octubre 2008) en el proceso entre Ausbanc y la Caja de Ahorros de Madrid. En el préstamo a interés variable destinado a la adquisición de viviendas se disponía que el tipo de interés nominal previsto en el contrato, variable por períodos, debía redondearse (es decir, elevarse) al cuarto de punto porcentual superior desde la primera revisión.

${ }^{24}$ Vid. párrs. 27 y 30 de la sentencia. El Juzgado de Primera Instancia (JPI) núm. 2 de Sabadell sustanciaba la ejecución de un préstamo en modalidad contractual de adhesión para adquirir un vehículo por importe de 30.000 euros. El juez apreció que las cláusulas que fijaban los intereses de demora eran presuntamente abusivas al señalar un interés retributivo del 7,950 \% (TAE 8,890\%) y el interés de demora del 29 $\%$, es decir, sobrepasaba el interés retributivo en más de 20 puntos atendiendo al tipo Euribor y el del Banco Central Europeo. En consecuencia, fijó el interés de demora en un $19 \%$ basándose en el interés legal y en el interés de demora establecidos en las Leyes de Presupuestos de 1990 a 2008, y requirió a Banesto para que procediera a un nuevo cálculo del importe de los intereses para el período que se discutía en el litigio (párr. 30). El banco apeló el auto y la Audiencia de Barcelona planteó la cuestión prejudicial al TJUE. 
que había que considerar el artículo 83 del TRLGDCU contrario al artículo 6.1 de la Directiva 93/13/CEE (punto 2 de su declaración) ${ }^{25}$.

Por último, la STJUE de 14 de marzo de 2013 (asunto C-415/11, Aziz $)^{26}$. El TJUE dio la razón al juez en las cuestiones procesales, pero en los temas sustantivos no se pronunció. El Tribunal tan sólo recordó al juez remitente que la competencia del TJUE comprende la interpretación del concepto de cláusula abusiva, limitándose a darle las indicaciones o los criterios que debe tener en cuenta para apreciar el carácter abusivo de la cláusula a la luz de las disposiciones de la Directiva (párr. 66). Pero la competencia para calificar una cláusula como abusiva corresponde al juez nacional ${ }^{27}$. Con relación al desequilibrio importante, el juez deberá analizar, a falta de acuerdo entre las partes, en qué medida el contrato deja al consumidor «...en una situación jurídica menos favorable que la prevista por el Derecho nacional vigente» (párr. 68 y punto 2 de la declaración).

2. Doctrina del TJUE en la sentencia del Tribunal Supremo de 9 de mayo 2013.

Del análisis de la meritada sentencia se extrae la siguiente relación de principios:

1. Las cláusulas abusivas no vinculan al consumidor. Por tanto, el juez que declare abusiva una cláusula (en el marco de una acción de cesación) también deberá aplicar de oficio todas las consecuencias previstas en su Derecho nacional para que los

${ }^{25}$ La sentencia determinará la modificación del citado artículo 83 , lo que se produjo por el artículo único. 27 de la Ley 3/2014, de 27 de marzo, por la que se modifica el texto refundido de la Ley General para la Defensa de los Consumidores y Usuarios y otras leyes complementarias, aprobado por el Real Decreto Legislativo 1/2007, de 16 de noviembre.

${ }^{26}$ El Juzgado de lo Mercantil (JM) núm. 3 de Barcelona, que sustancia un juicio declarativo tras un proceso de ejecución hipotecaria, plantea varias cuestiones al TJUE, una de índole procesal, y otras en torno al concepto de desproporción en relación con el vencimiento anticipado en contratos de larga duración (en este caso 33 años) y la fijación de unos intereses de demora superiores al $18 \%$, que en otros ámbitos de la contratación de consumidores se podrían entender abusivos (párr. 31.2).

${ }^{27}$ Igualmente en los párrafos 44 de las SSTJUE de 4 de junio de 2009 (asunto C-243/08, Pannon GSM Zrt), con causa en un contrato de prestación de servicios de telefonía móvil, y de 9 de noviembre de 2010 (asunto C-137/08, VB Pénzügyi), que enjuicia un préstamo destinado a financiar la compra de un vehículo. 
consumidores no resulten vinculados por ninguna de ellas si le resultan de aplicación a su contrato ${ }^{28}$.

2. ${ }^{\circ}$ Los principios de buena fe, equilibrio y transparencia en el caso Vertrieb (STJUE de 21 de marzo de 2013, asunto C-92/11) ${ }^{29}$. El litigio tenía por objeto un contrato de suministro de gas natural celebrado en régimen de libertad entre una empresa suministradora y consumidores. El clausulado general remitía a la normativa nacional reguladora de contratos tarifados, lo que no sólo significaba la sujeción del contrato a una normativa que no era aplicable a dichos contratos, sino que permitía al proveedor modificar unilateralmente el precio del gas sin indicar la causa, las condiciones o el alcance de la modificación, no obstante garantizar a los clientes la información y el derecho a denunciar el contrato (párr. 18). El Tribunal interpreta que para apreciar si este tipo de cláusulas obedecen o no a las exigencias de buena $\mathrm{fe}$, equilibrio y transparencia que imponen tales disposiciones, resulta esencial determinar si en el contrato se expone de manera transparente el motivo y el modo de variación de tal coste, de forma que el consumidor pueda prever, sobre la base de criterios claros y comprensibles, las eventuales modificaciones de ese coste. La falta de información previa a la celebración del contrato no puede ser compensada, en principio, con la información suministrada al consumidor durante la ejecución del contrato, ni con su derecho a rescindirlo si no desea aceptar la modificación.

3. La limitación en el tiempo de los efectos (retroactivos) de la sentencia. Cuando empresas y gobiernos de los Estados miembros han solicitado la declaración de dicho efecto, el Tribunal ha dado la misma respuesta cualquiera que fuera la relación jurídica de la que trajera causa la cuestión prejudicial, que también se transcribe en el asunto Vertrieb:

${ }^{28}$ STJUE de 26 de abril de 2012, asunto C- 472/10, Invitel, párr. 43, punto 2) de la declaración, párr. segundo.

${ }^{29}$ Interpretación de los arts. 3 a 5 de la Directiva 93/13 CEE, en relación con el art. 3, ap. 3, Directiva 2003/55/CE del Parlamento Europeo y del Consejo, de 26 de junio de 2003, sobre normas comunes para el mercado interior del gas natural. Téngase presente que en ésta Directiva, la transparencia constituye principio jurídico indefinido: es requisito de acceso a la red para un funcionamiento correcto de la competencia (Considerando 7); de las obligaciones de servicio público (artículo 3. 2), de la información general y los mecanismos de resolución de conflictos (art. 3,3); requisito informativo sobre precios, tarifas y condiciones generales (Anexo A, letra c); un principio contable para las Compañías de gas natural (Capítulo V) y de los mecanismos de control que deben crear los Estados para evitar los abusos de la posición dominante (art. 25,8), etc. 
- El juez nacional debe aplicar la interpretación del Tribunal sobre una norma comunitaria a relaciones jurídicas nacidas antes de la sentencia prejudicial ${ }^{30}$.

- El Tribunal de Justicia, excepcionalmente, puede limitar aquellos efectos en la misma sentencia que resuelve sobre la interpretación solicitada, aplicando el principio general de seguridad jurídica comunitario si concurren necesariamente dos requisitos esenciales: la buena fe de los círculos interesados y el riesgo de trastornos graves ${ }^{31}$. La posición del TJUE es muy antigua al respecto a pesar de que en dos ocasiones admitió la limitación de los efectos de su interpretación ${ }^{32}$. El Tribunal reitera el mismo razonamiento: las consecuencias prácticas de cualquier decisión judicial deben ser cuidadosamente ponderadas, pero no se puede vulnerar la objetividad del Derecho y poner en peligro su futura aplicación a causa de las repercusiones que con respecto al pasado pueden derivarse de tal decisión judicial.

- Únicamente se permitiría el TJUE limitar en el tiempo los efectos de su sentencia cuando existiera un riesgo de repercusiones económicas graves y para salvaguardar el principio de seguridad jurídica ${ }^{33}$, circunstancia que, salvo en el caso Blaizot, no consideró probada en ninguno de los restantes citados por el TS en el punto 2.3 del FJ Decimoséptimo.

Ahora bien, ¿dónde reside esa potestad del TJUE? Entre las competencias del Tribunal se halla el recurso de anulación. Este recurso tiene por objeto actos legislativos de la Instituciones de la Unión Europea que gozan de eficacia sobre terceros (art. 263, párrafo primero

${ }^{30}$ STJUE de 10 de enero de 2006, asunto C-402/03, Skov y Bilka, indemnización de perjuicios sufrido por los perjudicados a raíz del consumo de huevos (párr. 50); STJUE de 18 de enero de 2007, asunto C-313/05, Brzezinsky compra en Alemania un coche Volkswagen fabricado en 1989 que posteriormente importó a Polonia (párr. 55); Vertrieb (párr. 58); STJUE de 2 de febrero de 1988, asunto C-24/86, Blaizot (párr. 27).

${ }^{31}$ STJUE de 3 de junio de 2010, asunto C-2/09, Kalinchev compra en Francia un automóvil de segunda mano y lo importa a Bulgaria, tributa impuestos especiales (párr. 50); Skov y Bilka (párr. 51), Brzezinsky (párr. 56), Vertrieb (párr. 59), Blaizot (párr. 28).

${ }^{32}$ Vid. STJUE de 8 de abril de 1976, asunto 43/75, Defrenne, párr. 71, y el citado Blaizot, párr. 30 .

${ }^{33}$ El TJUE exige además un elevado número de relaciones jurídicas constituidas de buena fe, una normativa considerada válida y que fuera patente que los particulares y las autoridades nacionales habían sido incitados a observar una conducta contraria a la normativa comunitaria. Pero las consecuencias financieras que podrían derivarse para un Estado miembro no justifican, por sí solas la limitación de los efectos de la sentencia en el tiempo (Brzezinsky, párrs. 57 y 58; Kalinchev, párrs. 51 y 52). 
TFUE). Si el TJUE lo estimara necesario, podría moderar los efectos retroactivos —ex tunc - de la nulidad, a tenor del segundo párrafo del artículo 264 TFUE cuando dice «... indicará aquellos efectos del acto declarado nulo que deban ser considerados como definitivos» ${ }^{34}$. Esta potestad se funda en la necesidad de proteger la confianza legítima de los particulares en el acto legislativo (Reglamento, Directiva o Decisión) a la postre ilegítimo o inconstitucional ${ }^{35}$. Pues bien, el TJUE ha aplicado analógicamente este precepto a los casos de prejudicialidad sobre la validez de los actos adoptados por las instituciones, órganos u organismos de la UE (art. 267, antiguo 234 TFUE) y a las cuestiones prejudiciales de interpretación que, como hemos visto, no ponen en duda la legalidad del Derecho comunitario sino, en todo caso, la del derecho nacional.

\section{LAS CLÁUSULAS SUELO EN LAS INSTANCIAS JUDICIALES}

La justicia española ha admitido mayoritariamente que la cláusula suelo sea una condición general de la contratación (art. 1.2 LCGC, art. 3.2 Directiva 93/13/CEE y art. 59.3 TRLGDCU); predispuesta, al haber sido elaborada de forma unilateral y previa por el predisponente operador bancario; incorporada con carácter no masivo a una pluralidad de contratos, y no negociada ${ }^{36}$. La normativa bancaria que la ha previsto le confiere apariencia de licitud y también de condición general, pero «... no impone la existencia de cláusulas suelo, ni en defecto de pacto supone su existencia ni, finalmente, indica los términos en los que la cláusula viene expresada en el contrato» (STS de 9 de mayo de 2013, párr. 174) ${ }^{37}$.

La Audiencia Provincial de Sevilla lideró la posición judicial contraria en su sentencia de 7 de abril de 2011, resolutoria del recurso de

${ }^{34}$ «Eficacia prospectiva» o «ex nunc» de la sentencia. Cfr. BACIGALUPO SAGESSE, «El sistema jurisdiccional de la Unión Europea», cit., pág. 522.

${ }^{35}$ Op. cit., pág. 523: «...la seguridad jurídica puede oponerse a una expulsión inmediata y retroactiva del ordenamiento jurídico europeo del acto normativo anulado sin que previamente sea sustituido por otro conforme a Derecho».

${ }^{36}$ SJM núm. 2 Sevilla, 30.9.2010, FD Tercero; SJM núm. 2 Palma Mallorca, 2.2.2012, FD Tercero; SJM núm. 1 León, 11.3.2011, FD Cuarto; sentencia del Juzgado de Primera Instancia e Instrucción de Cáceres (SJPIeI), 18.10.2011, FD Tercero; sentencias de la Audiencia Provincial (SSAP) de Cáceres; 24.4.2012, FJ Tercero; 19.6.2012, FJ Segundo; 18.7.2012, FJ Tercero.

${ }^{37}$ Por tanto, no han prosperado las tesis defendidas por las entidades bancarias tendentes a eludir la aplicación de la LDGCU, la LCGC o el TRLGDCU, tales como que la cláusula suelo es fruto de un pacto consensuado entre las partes, libremente concertado o al menos aceptado o consentido por los prestatarios. 
apelación contra la sentencia de 30 de septiembre de 2010 del Juzgado de lo Mercantil núm. 2 de Sevilla. La Audiencia negó la naturaleza de condición general de la cláusula suelo partiendo de un planteamiento disyuntivo de la cuestión: o los pactos de limitación de intereses variables constituyen una condición general de la contratación, predispuesta e impuesta por la entidad crediticia, o no lo son sino elementos esenciales del contrato de préstamo. Con abundantes razonamientos (FD Quinto) niega lo primero, pues constituyen los términos financieros del préstamo, están incluidas en la oferta vinculante que la entidad debe hacer al prestatario y, aceptada la oferta, se incorporan al contrato siendo el precio del mismo ${ }^{38}$.

La contradicción de la justicia sevillana será objeto de casación y resuelta en la STS de 9 de mayo de 2013 en los siguientes términos:

- Las cláusulas suelo se refieren al objeto principal del contrato en el que están insertadas y pueden ser calificadas como condición general de la contratación, que se definen por el proceso seguido para su inclusión en el contrato (párr. 144 a).

- Las cláusulas predispuestas incluidas en ofertas estandarizadas son impuestas porque el consumidor medio no tiene ninguna posibilidad real de negociación aunque el consumidor muestre una conducta negociadora activa que sea rechazada (párr. 148).

- Consentir una cláusula predispuesta no desvirtúa su carácter impuesto si el consumidor no puede influir en su supresión o su contenido, de forma que se adhiere y contrata con dicha cláusula o renuncia a ello (párr. 165 a).

\section{EL CONTROL SOBRE LAS CLÁUSULAS ABUSIVAS QUE RECOGEN ELEMENTOS ESENCIALES DEL CONTRATO}

\section{A. El control en la doctrina de autores}

Era pacífico en la doctrina la existencia de dos tipos de controles sobre las cláusulas que contienen elementos esenciales en los contratos celebrados entre consumidores y empresarios. Uno, el control de inclusión o de incorporación. Denominado según su respectivo artículo, consiste en comprobar que el predisponente -Banco- observó

${ }^{38}$ Siguen este criterio la SAP Burgos, Sec. 3. a , 2.2.2012, FD Tercero; la SAP Madrid, Sec. 19, 13.7.2012, FD Cuarto, o la SAP Palma Mallorca, Sec. Quinta, 19.11.2012, FD Cuarto. 
una serie de requisitos formales para poder incorporar cláusulas a un contrato de consumo (en nuestro caso préstamo hipotecario): por una parte, transparencia, claridad, concreción y sencillez de las cláusulas (art. 5.4 LCGC); y a la inversa, que no sean ilegibles, ambiguas, oscuras e incomprensibles (art. 7, b LCGC) ${ }^{39}$. En este tipo de control se incluye el del consentimiento (art. 5.1 LCGC al referirse a la aceptación) pues lo lógico es que si las cláusulas reúnen esos requisitos sean aceptadas, y rechazadas en caso contrario.

El segundo control, el de contenido (art. 10 bis LGDCU), consiste en la posibilidad de declarar abusivas y nulas las estipulaciones no negociadas individualmente que, en contra de las exigencias de la buena fe, causen en perjuicio del consumidor un desequilibrio importante de los derechos y obligaciones que se deriven del contrato, sin olvidar las previstas en la relación de cláusulas de la Disposición adicional primera LGDCU, y las que contradigan normas imperativas o prohibitivas en perjuicio del adherente (art. 8.1 LCGC).

En la doctrina se añadió a estos controles indiscutidos un tercero que no gozaba de unánime aceptación, el de transparencia. Calificado de «tertium genus», se inspira en el formulado por la jurisprudencia alemana y se apoya en el inciso final del artículo 4.2 de la Directiva 93/13/ $\mathrm{CEE}^{40}$. Se trata de la posibilidad de que fueran declaradas nulas por abusivas las cláusulas que, por no ser redactadas de forma clara y comprensible, provocan subrepticiamente una alteración del equilibrio económico del contrato. Pertíñez, exponente principal de este tercer filtro, entiende que el deber de transparencia supone una triple garantía obligacional del predisponente: que el adherente pueda conocer el conjunto de derechos y obligaciones derivados del contrato mediante una redacción comprensible mediante su puesta a disposición, evitar que surjan dudas en el adherente sobre el sentido de las cláusulas, y asegurar que el

${ }^{39} \mathrm{El}$ precepto también permite considerar incorporadas las cláusulas ambiguas o ilegibles si hubieren sido expresamente aceptadas por escrito por el adherente y se ajustan a la normativa específica que disciplina en su ámbito la necesaria transparencia de las cláusulas contenidas en el contrato.

${ }^{40}$ Cfr. Cámara Lapuente, S., en "El control de las cláusulas abusivas...», cit., págs. 125 y 126, reconocía que el planteamiento era sugerente, pero advertía que debía valorarse la oportunidad de introducir esta doctrina en el Derecho español, puesto que no resulta patente que el art. 4.2 de la Directiva contenga un control de transparencia distinto del control de inclusión en el que tendría encaje. GonZÁlEz PaCANOWSCA, I., en "Comentario al artículo 7», en Bercovitz Rodríguez-Cano (Coordinador) y otros, Comentarios a la Ley de Condiciones Generales de la Contratación, Ed. Aranzadi, Navarra, 1999, pág. 249, recordaba que entre los autores alemanes algunos opinaban que la transparencia pertenece al ámbito de la inclusión, en tanto que el control del contenido no podía ser sólo formal sino que debía ir siempre ligado a un desequilibrio material. 
adherente conozca antes de la celebración del contrato el montante total del precio y las características esenciales de la contraprestación ${ }^{41}$.

\section{B. El control realizado por juzgados y Audiencias Provinciales hasta la STS de 9 de mayo de 2013. La antijuridicidad de las cláusulas suelo como cláusulas abusivas}

La antijuridicidad de la cláusula suelo, como condición general, predispuesta y no negociada individualmente, requería, entre otros elementos normativos, la vulneración de la buena fe como causa de un desequilibrio importante en los derechos y obligaciones del contrato y la existencia de un desequilibrio entendido como falta de reciprocidad contractual (arts. 3. 1 y 4. 1 Directiva 93/13/CEE, art. 8 LCGC, y art. 82.1 y 3 TRLGDCU) ${ }^{42}$.

Pero la buena fe también tiene exigencias en cuanto a la transparencia de las cláusulas contractuales reguladoras del precio ${ }^{43}$. Para el TS, la buena fe exige que el consumidor esté "perfectamente informado del comportamiento previsible del índice de referencia cuando menos a corto plazo, de tal forma que cuando el suelo estipulado lo haga previsible, esté informado de que lo estipulado es un préstamo a interés fijo mínimo, en el que las variaciones del tipo de referencia a la baja probablemente no repercutirán o lo harán de forma imperceptible en su beneficio» (STS de 9 de mayo de 2013, párr. 256).

Por otra parte, la falta de reciprocidad o equilibrio contractual en las cláusulas suelo-techo ha generado un amplio debate procesal que con seguridad no habría llegado tan lejos si la cláusula suelo fuera tuviera una configuración o estructura típica (art. 87 TRLGDCU). Las sentencias han dejado ver dos posiciones judiciales claramente opuestas. Entre los argumentos favorables a la declaración de abusividad de la cláusula suelo por vulneración del citado principio y consiguiente sanción de nulidad cabe anotar:

${ }^{41}$ Cfr. Pertíñez Vílchez, F. y otro «Los contratos de adhesión y la contratación electrónica», en Bercovitz RodRíGuEz-CANo, R. y otros, Tratado de contratos, Tomo II, edición 2. a , Ed. Tirant Lo Blanch, Valencia, 2013, pág. 1801.

42 SJM núm. 2 Málaga, 20.12.2011, FD Séptimo; SJM núm. 7 Barcelona, 12.9.2011, FD Tercero.

${ }^{43}$ Vid. el párrafo Primero del Voto Particular del Magistrado Rafael Sarazá Jimena en la SAP Madrid Sec. 28, 22.3.2007: «el adherente tiene derecho a esperar que el predisponente no introduzca, mediante condiciones generales no transparentes, una reglamentación contractual que entre en contradicción con el equilibrio entre precio y prestación que el adherente legítimamente se representó al contratar...». 
1. La reciprocidad contractual también es reciprocidad económica, por eso, un pacto que cubriese los intereses de ambas partes sin guardar una razonable equivalencia o semejanza entre la limitación del interés al alza y a la baja faltaría a la reciprocidad ${ }^{44}$.

2. La incapacidad económica de los prestatarios para asumir las subidas de los tipos de interés lleva a colegir que «la entidad bancaria se ha debido de representar como más que improbable las subidas del Euribor ${ }^{45}$.

3. Un reparto desigual de los riesgos debido a que el suelo es efectivo frente a un techo inefectivo por irreal, que no protege eficazmente al prestatario del riesgo de subidas ${ }^{46}$.

4. La absoluta desproporción entre suelos y techos acredita un desequilibrio contractual que afecta a la propia sustancia del contrato y supone una alteración sustancial del pacto del tipo de interés variable ${ }^{47}$, o, en otras palabras, la alteración del valor de la oferta a partir de la información proporcionada por el empresario, teoría que ya tuvo un amplio debate doctrinal.

5. La inexistencia en los préstamos hipotecarios de alguna contrapartida consensuada en beneficio del consumidor, exigencia impuesta por la ley al hablar de equilibrio ${ }^{48}$.

6. Incluso la falta de reciprocidad ha sido vista como abuso igualado con la usura ${ }^{49}$.

${ }^{44}$ SJM núm. 2 Sevilla, 30.9.2010, FD Cuarto; SJPIeI núm. 1 Cáceres, 18.10.2011, FD Quinto, razona la idea de un equilibrio o reciprocidad económica perfecta con la fijación de un tipo variable (Euribor) que ofreciera ventajas objetivas para las dos partes, de manera que si el Euribor baja, la entidad bancaria corra el riesgo, beneficiándose correlativamente el consumidor; pero si el Euribor sube, sea el consumidor quien corra el riesgo de perjudicarse, beneficiando al banco o caja.

${ }^{45}$ SJM núm. 2 Málaga, 20.12.2011, FD Séptimo.

${ }^{46}$ SJM núm. 1 León, 11.3.2011, estimó parcialmente la pretensión al valorar de esa forma una cláusula techo del $12 \%$ (FD Sexto).

${ }^{47}$ SSAP Sec. 1 Cáceres, 24.4.2012, FFDD Octavo y Noveno; 19.6.2012, FD Quinto; y 18.7.2012, FD Sexto.

${ }^{48}$ SJPIeI núm. 1 Cáceres, 18.10.2011, FD Quinto; SAP Burgos, 2.2.2012, FD Segundo.

${ }^{49}$ SJM núm. 2 Palma Mallorca, 2.2.2012. La Magistrada señala que el techo fijado por la entidad crediticia «se ha igualado sin rubor alguno a los estratosféricos intereses del $28 \%$ que entran de lleno y con todos los honores en la calificación de usuarios y leoninos conforme al artículo 1 de la Ley de 23 de julio de 1908», y no desaprovecha la ocasión para evocar un símil bíblico: «...aquí estamos presenciando el ejemplo claro de las consecuencias de una posición desigual y del poder de la entidad de crédito frente al consumidor, es la representación de David contra Goliath....» (FD cuarto, último párrafo). 
Entre los argumentos contrarios a la declaración de abusividad de las cláusulas suelo por vulneración del principio de reciprocidad contractual o causar desequilibrio en las prestaciones se incluyen un conjunto de razonamientos jurídicos unidos por un denominador común, la inexistencia de reciprocidad contractual en el contrato de préstamo. Cabe citar:

1. La legalidad de las cláusulas suelo y techo al estar previstas en la Orden de 5 de mayo de 1994.

2. Las acotaciones al tipo de interés constituyen parte integrante del precio mismo del préstamo, el cual se corresponde con los intereses remuneratorios ${ }^{50}$. El prestamista (entidad bancaria) dispone de las más amplias facultades para determinar las condiciones (el tipo resultante) en que se va a producir la devolución del principal y también cuál va a ser el coste del présta$\mathrm{mo}^{51}$. Frente a esa facultad se reconoce al consumidor su libertad para no contratar, de acuerdo con sus expectativas económicas, o a contratar otro producto semejante ofrecido por otra entidad competidora si considera superiores sus características.

3. El precio del contrato es determinado por el mercado en régimen de libre competencia. Si el juez interviniera en su fijación decidiría sobre un elemento esencial del contrato, le exigiría realizar un juicio de previsión de ciclos macroeconómicos sin más sustento que la evolución del Euribor en el periodo precedente, podría producir efectos no deseados en la competencia e incluso afectar negativamente a la posición de la entidad en el mercado. El precio sólo está sometido, por un lado, a los límites de transparencia y claridad, y por otro, a los límites de la Ley Azcárate ${ }^{52}$.

4. El prestatario ha aceptado el riesgo de las fluctuaciones en el precio durante la vida del contrato.

5. Las cláusulas suelo y techo no se corresponden con ninguna otra contraprestación del banco, cuya única obligación es la de entregar el dinero al prestatario ${ }^{53}$.

${ }^{50}$ SJM núm. 9 Madrid, 8.9.2011, párr. 26; SJM núm. 2 Alicante, 23.6.2011, FD Tercero.

${ }^{51}$ SAP Burgos, 2.2.2012, FD Tercero.

${ }^{52}$ SJM núm. 9 Madrid, 8.9.2011, párrafos 23, 24, y 27.

${ }^{53}$ SAP Sevilla Sec. Quinta, 7.10.2011, FD Sexto: «Resulta muy osado declarar la desproporcionalidad cuando ni tan siquiera hemos sido capaces de concretar cuál sea el punto de equilibrio, la referencia respecto de la cual podamos apreciar que 
En la sentencia de 9 de mayo de 2013, el TS reconoce que «No existe en el Derecho de la Unión, ni en el Derecho nacional norma alguna que refiera el desequilibrio entre los derechos y obligaciones exclusivamente a los contratos bilaterales con obligaciones recíprocas, aquéllas en las que los sujetos son a la vez acreedores y deudores entre sí, de tal forma que la prestación de cada una de las partes constituye para la otra la causa de la propia...» (párr. 243). Pero más tarde afirma: «No es preciso que exista equilibrio «económico» o equidistancia entre el tipo inicial fijado y los topes señalados como suelo y techo máxime cuando el recorrido al alza no tiene límite» (párr. 257). Así, el TS dejaba claro que no acepta la reciprocidad contractual en el tema de las cláusulas dinerarias de un préstamo hipotecario.

En cuanto al análisis de las circunstancias («todas») concurrentes en la celebración del contrato, los juzgados han realizado valoraciones sobre la evolución del mercado financiero y de los valores inmobiliarios no sólo al tiempo de celebración del contrato sino incluso desde períodos inmediatos anteriores hasta el mismo momento del litigio ${ }^{54}$. Siendo los argumentos irrefutables no encajan exactamente en la literalidad del precepto (art. 82.3 TRLGDCU) por razonable que haya sido la interpretación judicial, de manera que, a mi modo de ver, las sentencias que contienen tales discernimientos evidencian la preponderancia del término «todas» sobre la realidad existente en el momento de celebrar el contrato. Sea como

el fiel de la balanza se escora indebidamente hacia uno de los lados. Baste al respecto un ejemplo..... Si tenemos en cuenta que en julio de 2008 el Euribor estaba al 5,393\%, o en octubre de 2008 al 5'248\%, y a ese porcentaje le añadimos el diferencial del $1,50 \%$, el interés que pagaba el prestatario en ese momento estaba prácticamente a la misma distancia del techo que del suelo. Es decir, los tipos fluctúan, los préstamos son de larga duración, el comportamiento de los mercados financieros a largo plazo es muy difícil de predecir. Ante ello y no disponiendo en estos autos de una prueba pericial que hiciese un profundo estudio científico de la cuestión, no es posible declarar con cierto fundamento y rigor que haya un desequilibrio importante o falta de equivalencia entre el límite mínimo del tipo y el máximo».

${ }^{54}$ SAP Cáceres, 19.6.2012, FD Quinto: El Euribor «desde el año 2000 en pocas ocasiones ha subido por encima del $5 \%$, y si ha subido nunca llega al $6 \%$. Ante la alegación de la entidad bancaria tenida como cierta de que otros índices de referencia en los préstamos hipotecarios (CECA o MIBOR) han alcanzado históricamente registros superiores al 12\%, la Audiencia responde que no cabe descontextualizar dicho dato de las circunstancias existentes en el momento en que se produjo, y esas circunstancias revelan «un precio de mercado de la vivienda infinitivamente inferior al que ha conocido en los últimos años, y una duración correlativa del período pactado para la devolución del préstamo también notablemente más reducida». O también la SJPIeI núm. 1 Cáceres, 18.10.2011, FD Quinto, y la SJM núm. 1 León, 11.3.2011, FD Sexto. 
fuere, este mandato normativo permitiría la operatividad de la cláusula «rebus sic stantibus». En este sentido, Nasarre estima injustificable el pacto de antemano de tan diferentes cláusulas techo y suelo y que la parte perjudicada podrá alegar la cláusula «rebus sic stantibus» para solicitar el reequilibrio de las prestaciones (STS de 25-1-2007) $)^{55}$.

\section{El control de los elementos esenciales en la doctrina del Tribunal Supremo}

1. Precedentes inmediatos de la STS de 9 de mayo de 2013 desde la STJUE de 3 de junio de 2010 (Caja Madrid)

La STS de 1 de julio de 2010 enjuicia la abusividad de condiciones generales en seguros de vida. Ante la falta de transposición del artículo 4.2 de la Directiva a la norma nacional, razona el Tribunal que la legislación de consumo no diferencia entre cláusulas abusivas referidas, por un lado, a la definición del objeto principal del contrato y a la adecuación entre precio y contrapartida, y, por otro, cláusulas con otro contenido. En consecuencia, vinculada la sentencia por la del TJUE, confirma la posibilidad del control jurisdiccional de abusividad de las cláusulas no negociadas individualmente que se refieran al objeto principal del contrato, incluso si fueran claras y comprensibles (párr. 74.2 y 80) ${ }^{56}$.

En las SSTS de 4 de noviembre de 2010 (AUSBANC vs. Caja Provincial de Ahorros de Jaén), y de 29 de diciembre de 2010 (AUSBANC vs. Caixa d'Estalvis de Tarragona) se debate la posibilidad de un control judicial del contenido de las cláusulas litigiosas de redondeo al alza. El TS responde literalmente con la interpretación del apartado segundo del artículo 4 de la Directiva 93/13/CEE contenida en la STJUE de 3 de junio de 2.010. En los dos casos el TS confirmó la abusividad de la cláusula declarada en primera instancia y confirmada por la Audiencia Provincial.

${ }^{55}$ Cfr. NASARRE AzNAR, S. «Malas prácticas bancarias en la actividad hipotecaria», Revista Crítica de Derecho Inmobiliario, núm. 727, 2011, págs. 2676-2677.

${ }^{56}$ Para CÁmARa LAPUente es la más clara afirmación del TS sobre la licitud de dicho control en el Derecho español. Cfr. en CÁmara LAPUEnTE S., «¿De verdad puede controlarse el precio de los contratos mediante la normativa de cláusulas abusivas? De la STJUE de 3 junio 2010 (Caja de Madrid, C-484/08) y su impacto aparente y real en la jurisprudencia española a la STS (pleno) de 9 mayo 2013 sobre las cláusulas suelo», Cuadernos de Derecho Transnacional, Octubre 2013, Vol. 5, núm. 2, pág. 224. 
El TS reconoce obiter dicta (STS de 9 de mayo de 2013, párr. 195) que las sentencias citadas admitieron el control de contenido de condiciones generales referidas al objeto principal del contrato, salvo en la sentencia de 18 de junio de 2012 en la que, constatando las discrepancias doctrinales, cambió su posición interpretando, "por aplicación teleológica de la Directiva del 93, artículo 4.2» que los elementos esenciales del contrato se hallan excluidos del control de contenido, pero pueden ser objeto de control de inclusión y de transparencia según los artículos 5.5 y 7 de la LCGC y el artículo 10.1. a) de la LGDCU (FD Segundo, 3 d). En suma, no cabe un control del precio abusivo ${ }^{57}$.

2. El control de transparencia en la STS de 9 de mayo de 2013.

Partiendo de la licitud $a b$ initio $^{58}$ de las cláusulas suelo, el TS aplica un doble control de transparencia sobre las condiciones generales que contienen elementos principales del contrato (FD Decimoprimero). Además del control de inclusión o de incorporación al contrato (arts. 5.5 y 7 LCGC) que el Tribunal conecta con los deberes informativos explícitos en la OM 1994, existe un segundo control, el de transparencia, aplicable si las cláusulas han superado el control de inclusión o incorporación (párr. 204). La transparencia constituye para el TS un «parámetro abstracto de validez de las cláusulas predispuestas» (párr. 210) que excluye el error vicio (art. 1.266 Código Civil) al momento de celebrar el contrato, y, cuando se proyecta sobre los elementos esenciales del contrato, significa:

a) En cuanto a la carga económica, que el adherente conozca o pueda conocer con sencillez su sacrificio patrimonial a cambio de la prestación patrimonial que quiere obtener (párr. 210), y las eventuales modificaciones del coste (párr. 214, citando la STJUE Vertrieb).

${ }^{57}$ El caso enjuiciado consistía en un contrato de préstamo por valor nominal de 158.000 euros, con garantía hipotecaria y a un interés nominal anual del $20,50 \%$, suscrito el 11 de julio de 2006 con vencimiento al 1 de agosto de 2007, es decir, algo más de un año. La parte demandante ejercitaba una acción de nulidad de la Ley de Usura y acumulaba subsidiariamente la de nulidad por abusividad conforme al artículo 10.1 a) y 2 de la Ley 26/1984. El TS hace un recorrido histórico de nuestro sistema contractual, remontándose a las Partidas hasta llegar a la libertad de precios como pieza maestra de la doctrina liberal en materia de contratos. Merecen ser comparados estos razonamientos con los desarrollados en los párrafos 140 y 142 de la STS de 9 de mayo de 2013 (FD Segundo).

${ }^{58}$ Incondicionalmente (párr. 293, a); condicionadamente (párr. 256); aunque no coexistan con cláusulas techo (párr. 258); y sin necesidad de equilibrio económico o equidistancia entre suelo y techo (párr. 257). 
b) En cuanto a la carga jurídica, conocer la distribución de los riesgos de la ejecución o desarrollo del contrato (párr. 210).

c) Transparencia significa «comprensibilidad real de su importancia en el desarrollo razonable del contrato» (párr. 215, b), excluye cláusulas enmascaradas entre informaciones abrumadoramente exhaustivas que dificultan su identificación y proyectan sombras sobre lo que considerado aisladamente sería claro (párr. 212). La información incompleta, insuficiente o inadecuada son propicias para la sorpresa, para revelarse engañosa o para desviar la atención del consumidor (párrafos 217, 218 y 219). Como conclusión, la transparencia según la LCGC de una cláusula no negociada individualmente, no excluye el control de su abusividad, aunque describa o defina el objeto principal del contrato, si no es transparente (párr. 215, a).

En consecuencia, el TS juzgó que las cláusulas suelo analizadas no eran transparentes porque se insertaban en forma conjunta con la cláusula techo, calificadas como señuelo y como contraprestación aparente de aquéllas; porque no han existido simulaciones («escenarios diversos") del comportamiento razonablemente previsible del tipo de interés en el momento de contratar, ni tampoco información sobre el coste comparativo con otras ofertas, y, por último, porque se hallaban enmascaradas entre una abrumadora cantidad de datos diluyendo la atención del consumidor (párr. 225) ${ }^{59}$.

La doctrina ha criticado esta construcción judicial de la transparencia informativa, pues el carácter abusivo de una cláusula no está basado en la infracción de obligaciones informativas. La exigencia informativa es tan alta que lleva a una cuasi universalización del carácter abusivo de la cláusula ${ }^{60}$. Por otro lado, el concepto de transparencia en la sentencia es novedoso pero nada tiene que ver con la claridad y la comprensibilidad de la cláusula en sí misma considerada, sino que lleva a valorar si el acuerdo sobre el precio y la contraprestación resulta distinto, en perjuicio del consumidor, del que legítimamente creía haber pactado.

${ }^{59}$ Argumentos recogidos en el párrafo Séptimo del Fallo junto con: a) la creación de la apariencia de un contrato de préstamo a interés variable; b) la falta de información suficiente de que se trata de un elemento definitorio del objeto principal del contrato; f) la inexistencia de advertencia previa clara y comprensible sobre el coste comparativo con otros productos de la propia entidad.

${ }^{60}$ Cfr. Pertíñez Vílchez, F., "Falta de transparencia y carácter abusivo...», cit., págs. 17-18. 
Desde otro punto de vista se afirma que la sentencia confunde y entremezcla el control de transparencia con el control de abusividad (párr. $210 \mathrm{y}$ siguientes) ${ }^{61}$.

A nuestro parecer, la crítica más demoledora es la que defiende que este tertium genu entre incorporación y abusividad por desequilibrio no existe en la Directiva 93/13/CEE ni tampoco en nuestro Derecho interno (art. 82 TRLGDCU), porque no hay una exigencia autónoma de transparencia sustancial como la que propone el Tribunal cuyo control pueda dar lugar per se a nulidad, sin que exista abusividad por desequilibrio censurable ${ }^{62}$. Para calificar como abusiva una cláusula suelo es indiferente si constituye o no un elemento esencial del contrato. Según esta posición, la construcción argumental atenta contra la seguridad jurídica al crear reglas y subreglas que llevarán a resultados impredecibles en futuras contiendas judiciales ${ }^{63}$.

\section{FALLOS Y EFECTOS}

Abstracción hecha de la naturaleza colectiva o individual de la acción ejercitada, las primeras sentencias muestran todas las soluciones imaginables ${ }^{64}$. Entre las Audiencias Provinciales, la sentencia de la Audiencia Provincial de (SAP) Sevilla, Sec. 5, de 7 de octubre de 2011,

${ }^{61}$ Cfr. Plaza Penadés, J., «Delimitación del control de transparencia de las condiciones generales de la contratación, sobre la base de la STS de 9 de mayo de 2013 sobre cláusulas suelo», Diario La Ley, núm. 8112, de 25 de junio de 2013, pág. 11.

${ }^{62}$ Cfr. Carrasco Perera, A y Cordero Lobato, E., «El espurio control de transparencia sobre condiciones generales de la contratación». STS de 9 de mayo de 2013, Revista CESCO de Derecho de Consumo, núm. 7/2013, págs.173 a 175. Señalan los autores, entre otros numerosos razonamientos, que este control no coincide con los controles propios relacionados con los defectos de información en el Derecho general de contratos, el error vicio del art. 1266 CC, y se aparta de los controles ejercitados por las Audiencias Provinciales y los Juzgados de lo Mercantil.

${ }^{63}$ Op. cit., pág. 176, CARRASCO y CORDERO consideran «inasible e inútil» el patrón contenido económico vs. contenido jurídico porque aplicado a la cláusula suelo el argumento es completamente reversible.

${ }^{64}$ Estimación íntegra de la demanda (SJM núm. 2 Sevilla, 30.9.2010), estimación parcial de la demanda (SJM núm. 1 León, 11.3.2011), desestimación total de la nulidad de las cláusulas suelo (SJM núm. 9 Madrid, 8.9.2011), desestimación de la nulidad de una cláusula pretendidamente sorpresiva que indujo a error en el firmante del préstamo (SJM núm. 2 Alicante, 23.6.2011), etc. Otro efecto propio de la nulidad de la cláusula es la condena a la entidad bancaria a la devolución de las cantidades cobradas en aplicación de dicha cláusula, más los intereses legales desde la fecha de cada cobro (SJM núm. 7 Barcelona, 12.9.2011; SJM núm. 2 Bilbao, 7.3.2013; SJM núm. 2 Palma Mallorca, 2.2.2012 y SJM núm. 2 Málaga, 20.12.2011). La SJM núm. 2 Málaga, 9.4.2013, concreta la forma de determinar el interés aplicable a las cantidades mensuales devengadas y abonadas en aplicación de la cláusula declarada nula. 
estimó la apelación de las entidades bancarias y declaró no haber lugar a la nulidad de las cláusulas suelo. En cambio, la SAP Burgos Sec. 3, de 2 de febrero de 2012, siguiendo la pauta marcada por la AP de Sevilla, desestimó la nulidad y, apenas mes y medio más tarde, la misma sección confirmaba una sentencia declarativa de nulidad por falta de reciprocidad en la cláusula (SAP Burgos, de 23 de marzo de 2012).

Las SSAP Cáceres Sec. 1, de 24 de abril, de 19 de junio y de 18 de julio del año 2012, confirmaron la nulidad declarada en primera instancia. En el mismo sentido, la SAP Palma de Mallorca Sec. 5, de 9 de noviembre de 2012.

La STS de 9 de mayo de 2013 declaró la nulidad de las cláusulas suelo y la consiguiente la nulidad parcial de los contratos (FD Decimosexto, y Séptimo del fallo) en base a la no identificación entre «objeto principal» con «elemento esencial», y al tratamiento dado a las cláusulas suelo por las demandadas, en el sentido de que no formen "parte inescindible» del tipo de interés, es decir, de su objeto y causa (párr. 274). En consecuencia, condena a las entidades bancarias a eliminar de sus contratos las cláusulas examinadas y a abstenerse de utilizarlas en lo sucesivo en la forma y modo en la que se utilizan, declarando la subsistencia del contrato sin las cláusulas suelo abusivas (párr. 276, y punto Octavo del Fallo) ${ }^{65}$.

No obstante conocer la posición contraria de la Comisión Europea $^{66}$, el TS declara la irretroactividad de la sentencia, por lo que la nulidad declarada no afectará a las situaciones definitivamente decididas por resoluciones judiciales con fuerza de cosa juzgada ni a los pagos ya efectuados en la fecha de publicación de la sentencia (Décimo del Fallo). El TS apoya su declaración en distintos argumentos como la limitación de los efectos de la «restitutio in integrum» (art. 1303 CC) que, según interpretación realizada por el Tribunal en la sentencia 118/2012, de 13 marzo, es «resultado natural de la propia nulidad de la reglamentación negocial» (párr. 28), el principio de seguridad jurídica ante el cual debe ser permeable una declaración de

${ }^{65}$ Cfr. Cañizares Laso, A., "Control de incorporación y transparencia de las condiciones generales de la contratación. Las cláusulas suelo». Revista de Derecho Civil, http://nreg.es/ojs/index.php/RDC, Vol. II, núm. 3 (julio-septiembre), 2015, pág. 92. Considera que la sentencia no justifica que la cláusula que no es transparente deba traspasar un control de contenido, a tenor del artículo 4.3 de la Directiva, y que de no traspasarlo deberá declararse abusiva y por consiguiente nula, ni tampoco explica cuáles son las consecuencias de la falta de transparencia «sustancial» de la cláusula incorporada.

${ }^{66}$ Informe de 27 de abril de 2000, de la Comisión, sobre la aplicación de la Directiva 93/13/CEE del Consejo, de 5 de abril de 1993, sobre las cláusulas abusivas en los contratos celebrados con consumidores. 
nulidad (párr. 287), la conservación de efectos consumados establecida en alguna legislación mercantil especial (marcas, patentes, etc), la doctrina del TC (párr. 288), evitar el enriquecimiento sin causa inherente a una restitución integral de las prestaciones (párr. 290) y la doctrina del TJUE tantas veces citada. Incluso valen cuestiones fácticas, como que no se trata de cláusulas inusuales o extravagantes, su tolerancia por el mercado durante cierto tiempo y el riesgo de graves trastornos en el sistemas económico (párr. 293).

Esta declaración levanta una barrera frente a la doctrina protectora del TJUE. La limitación impuesta impediría a los consumidores reclamar pagos indebidos más allá del 9 de mayo de 2013 si, no hallándose vinculados por la cosa juzgada de un proceso, estuvieran afectados por cláusulas suelo anteriores e idénticas a las enjuiciadas en la sentencia (párr. 294). En suma, lo pagado, pagado queda, aunque un juez, después del 9 de mayo de 2013, declarara abusiva la cláusula suelo de un préstamo hipotecario.

Nuestra doctrina científica, entre el estupor y la sorpresa, ha sido, puede afirmarse, unánime en la crítica a los argumentos manejados por el Tribunal. Así, se ha escrito que la sentencia mezcla el Derecho Privado con la Economía y que el TS ignoraba conscientemente que no puede excusar la aplicación de la ley porque los deudores, en este caso los Bancos, experimenten dificultades económicas al cumplirla ${ }^{67}$. Se ha calificado de insólita la interpretación del art. 1303 CC, resaltándose la incongruencia procesal de la sentencia en relación con el tipo de acción ejercitada (art. 53 TRLGDCU) ${ }^{68}$, así como que el Tribunal no debiera prejuzgar la improcedencia de devolver cantidades percibidas de modo abusivo (intereses excesivos indebidos), pues a tal solución lleva la LCGC (art. 12.2, segundo párrafo). Al negar el Tribunal el derecho a la restitución impone a los consumidores un sacrificio incomparable con los beneficios obtenidos por las entidades financieras $^{69}$. Y, en fin, Pertíñez, sobre el principio de seguridad jurídica afirma que la sentencia hace una auténtica llamada a la libre interpre-

${ }^{67}$ Cfr. Míquel Rodríguez, J. M., «Condiciones generales abusivas en los préstamos hipotecarios», Revista Jurídica de la Universidad Autónoma de Madrid, núm. 27, 2013-I, págs. 249-250.

${ }^{68}$ Cfr. Pertíñez Vílchez, F., «La restitución de las cantidades indebidamente cobradas en virtud de cláusulas suelo en contratos de préstamo hipotecario tras la STS 9 de mayo de 2013», Diario La Ley, núm. 8154, de 23 septiembre de 2013, págs. 2-3.

${ }^{69}$ Cfr. García Montoro, L., «Contra la sentencia del Tribunal Supremo sobre cláusulas suelo: hay que devolver las prestaciones», Revista CESCO de Derecho de Consumo, núm. 6/2013, pág. 302. En el mismo parecer CAÑIZARES LASo, en «Control de incorporación y transparencia...», cit., pág. 98, manifiesta su desacuerdo con una decisión que impida la devolución de cantidades indebidamente cobradas. 
tación de las reglas procesales, hace saltar por los aires el principio de justicia rogada, contraviene el principio de contradicción y se arroga funciones cuasi legislativas ${ }^{70}$.

Por nuestra parte sólo añadiremos que el TS no ostenta potestad jurisdiccional para limitar los mal llamados efectos retroactivos de la sentencia ${ }^{71}$.

En cuanto a la cosa juzgada, el TS hace propia la razón del legislador (EM LEC), y para evitar una errónea generalización de los efectos subjetivos de la sentencia, es decir, para refrenar las expectativas que esta sentencia podía despertar en los consumidores (párr. 299), «unido al casuismo» del juicio de abusividad, según la información proporcionada, se ve obligado a ceñir los efectos erga omnes a quienes oferten en sus contratos cláusulas idénticas a las declaradas nulas...» (párr. 300).

\section{HACIA LA CONSOLIDACIÓN DE LA DOCTRINA DE LA TRANSPARENCIA}

\section{A. Repercusión de la STS de 13 de mayo de 2013 sobre sentencias posteriores}

Tras la STS de 13 de mayo de 2013, el efecto retroactivo derivado de la nulidad de la cláusula suelo se ha constituido como la cuestión neurálgica de los procesos, pasando las restantes cuestiones a un segundo plano. En todo caso y como predijeron los autores, las sentencias de los juzgados y de las Audiencias se alejaron de la uniformidad, ofreciendo claras discrepancias interpretativas y aplicativas de la doctrina del TS.

Unas sentencias siguieron aquella doctrina tomando como principales argumentos el especial deber informativo de la entidad bancaria y que no corresponde a los tribunales de instancia corregir la jurisprudencia del Tribunal Supremo (SAP Córdoba, de 31 de octubre de 2013, FD Séptimo). Por ello no se ponen trabas a reconocer un cambio en la posición propia (SSAP Cáceres, de 19 de noviembre de 2013, FJ Segundo, y de 24 de febrero de 2014, FJ Tercero) como signo de lealtad judicial al Alto Tribunal. Estas sentencias consideran

\footnotetext{
${ }^{70}$ Cfr. Pertíñez Vílchez, F., «La restitución de las cantidades... », cit., págs. 3-4.

${ }^{71}$ Cfr. Arias Rodríguez, J. M., «Notas sobre la jurisprudencia del Tribunal de Justicia respecto a las cláusulas abusivas», Diario La Ley, núm. 168, del 8 al 14 de febrero, 2016, pág. 7 .
} 
el riesgo de trastornos graves al orden público económico si se declarara la retroactividad de la sentencia y aplican el artículo 1.6 CC (SAP Badajoz, de 14 de enero de 2014, FJ Tercero), al que la SAP Zaragoza, de 8 de enero de 2014, se refiere "Acatando este precedente (STS 241/13) por la fuerza informadora de la jurisprudencia que el art. 1.6 del CC le atribuye...» (FD Cuarto).

Pero otras sentencias dictadas en primera instancia se apartaron de los criterios del TS en la apreciación de la causa de la nulidad y en el alcance de la restitución, como la sentencia del Juzgado de Primera Instancia e Instrucción núm. 4 de Orense, de 13 de mayo de 2013, que insiste en la abusividad de la cláusula suelo por la inexistencia de contrapartidas al riesgo real y efectivo que asume el consumidor y la total desproporción de la cláusula suelo (FD Undécimo), de ahí que condene a la entidad bancaria a devolver las cantidades cobradas de más, incluso las abonadas en exceso durante el procedimiento, y a recalcular el cuadro de amortización del préstamo hipotecario sin la cláusula suelo ${ }^{72}$. Estas sentencias no aprecian la existencia de riesgos de trastornos graves al orden público económico para limitar los efectos de la nulidad ${ }^{73}$, y en materia de cosa juzgada se justifica que no puede extenderse a quienes no fueron parte en el proceso (art. 223.3 LEC) hasta el punto de impedir a estos posteriores juicios (SJM núm. 1 Bilbao, de 19 de junio de 2013, FD Primero).

En el ámbito de las Audiencias, la SAP Málaga, de 12 de marzo de 2014 confirmó la sentencia de instancia que declaró la retroactividad total en base al artículo 9 LCGC en relación con el artículo 1303 CC, para evitar el enriquecimiento injusto del banco (FD Octavo). La SAP Barcelona, de 16 de diciembre de 2013, sostiene que la retroactividad es una consecuencia ineludible e implícita de la invalidez contractual y niega la identidad propia de la cosa juzgada material o de las circunstancias propias del caso enjuiciado con el de la sentencia del TS de referencia, no existiendo riesgo del orden público económico (párr. 17). La SAP Álava, de 9 de julio de 2013, sobre la base de que las acciones ejercitadas en la STS y en la del caso no son las

${ }^{72}$ En el mismo sentido, la SJM núm. 2 Málaga, 23.5.2013. La juzgadora no se siente vinculada por la construcción realizada por el TS sobre el principio de seguridad jurídica, la irretroactividad o la alteración del sistema de fuentes jurídicas y, tras citar literalmente unos 36 puntos de la STS de 9 de mayo de 2013, desaprueba en el FD Sexto al TS recordando que los Jueces y Tribunales tienen el deber inexcusable de resolver los asuntos conforme al sistema de fuentes, que establece la primacía de la Ley (arts. 1.303 y $1.1 \mathrm{CC}$ ) sobre la jurisprudencia (art.1,7 CC), razón ya anticipada en la SJPIeI núm. 4, Orense, 13.5.2013 (párr. 31).

${ }^{73}$ En particular, la SJM núm. 2 Málaga, 23.5.2013 (FD Sexto), o la SJM núm. 10 Barcelona, 7.6.2013 (párr. 29). 
mismas, también niega padecimiento en la economía nacional porque se restituya la cantidad indebidamente cobrada, sosteniendo la existencia de un claro enriquecimiento injustificado del banco frente a su cliente (FD Octavo). Por último, la SAP Zamora, de 28 de enero de 2015, en su FD Quinto, como hiciera la SAP Jaén, de 27 de marzo de 2014 (FD Tercero), detalla las posturas enfrentadas de las Audiencias Provinciales decantándose por la aplicación retroactiva de la nulidad que aprecia en las cláusulas y revoca la sentencia de instancia, dado que la irrectroactividad declarada por la STS de 9 de mayo de 2013 no se postula como criterio general al haberse ejercitado una acción de cesación.

\section{B. El TS ajusta su doctrina sobre la transparencia}

En tres señaladas sentencias el TS ha intentado perfeccionar su doctrina sobre la transparencia. En la sentencia de 8 de septiembre de 2014, el Tribunal reconoce la conveniencia de seguir afinando el fundamento técnico del control de una transparencia real (FD Segundo, párr. 4), no solo formal o reducida a la claridad o inteligencia gramatical de la cláusula. Ello significa que el prestatario ha de comprender verdaderamente los aspectos básicos del contrato, su onerosidad o su sacrificio patrimonial (párr. 6). Además, el predisponente (Banco) tiene unos «especiales deberes de configuración contractual en orden al equilibrio prestacional y a la comprensibilidad real de la reglamentación predispuesta» (FD Segundo, párr. 5) ${ }^{74}$. El cumplimiento de esos deberes se proyecta objetivamente en el curso de la oferta comercial y no tiene por objeto enjuiciar la validez del consentimiento otorgado sino la materialización del deber de transparencia en la reglamentación predispuesta (párr. 7$)^{75}$.

La STS de 24 de marzo de 2015 confirma que no es posible controlar el precio de un bien o servicio ante la falta de baremo o criterio jurídico que pueda delimitar y orientar ese control, y ratifica que son contrarias a la transparencia la utilización de cláusulas gramatical-

${ }^{74}$ El Tribunal tratará otra vez, en la sentencia de 24 de marzo de 2015, el polémico asunto del equilibrio entre precio y prestación, pero en ésta desde una singular perspectiva subjetiva, el equilibrio entre precio y prestación «tal y como se lo pudo representar el consumidor en atención a las circunstancias concurrentes en la contratación» (FD Tercero, punto 3, último párrafo).

${ }^{75}$ El TS se apoya ahora en la STJUE de 30 de abril de 2014 (asunto C-26/13, Kásler) que resolvió un caso de préstamo cuyo clausulado remitía la concreción de los pagos mensuales a un mecanismo de conversión de divisa extrajera. También lo hará en la citada sentencia de 24 de marzo de 2015. 
mente comprensibles y legibles pero que implican una subrepticia alteración económica del precio (FD Tercero), y la privación de la posibilidad de comparar entre las diferentes ofertas existentes en el mercado y hacerse una representación fiel del impacto económico que le supone el contrato (FD Tercero, párr. 3; FD Séptimo, párr. 2).

En último lugar, la STS de 25 de marzo de 2015. El tema central de la sentencia es el reintegro de cantidades como consecuencia de la condición nula, pero con carácter previo trata la cosa juzgada producida por la sentencia de 9 de mayo de 2013. Tras analizar las soluciones dadas por la doctrina, el Tribunal entiende que no procede estimar tal efecto en relación con «la restitución o no de los intereses pagados en aplicación de la cláusula declarada nula» porque esa acción no fue ejercitada en el proceso (FD Quinto). Pero a efectos de resolver la cuestión de la retroactividad, el TS reconoce ahora la identidad en el conflicto jurídico, se trate de una acción colectiva o de una individual, y, recordando los principales razonamientos de aquélla sentencia, reitera la limitación de efectos restitutorios más allá de la fecha de publicación de la sentencia de 9 de mayo de 2013 (FD Noveno y punto 3 del Fallo), eso sí, sin que falte loa del criterio establecido en la tantas veces citada sentencia de la que dice «abre los ojos y las mentes de las partes contratantes»(FD Décimo).

\section{CONCLUSIONES. POST SCRIPTUM}

1. ${ }^{\mathrm{a}}$ Asociaciones y consumidores plantearon sus demandas en base a la violación del principio legal de reciprocidad contractual sobre el hecho concreto que la cláusula suelo impedía a los prestatarios beneficiarse de las bajadas constantes de los tipos de interés, con el efecto de encarecer el préstamo hipotecario concertado a interés variable.

2. ${ }^{\text {a }}$ El TS ha analizado la legalidad de la cláusula suelo bajo el prisma de su transparencia, considerado en un doble sentido, formal o gramatical y material. Así, no se trata solamente de que el clausulado de la escritura del préstamo responda gramaticalmente a las exigencias de claridad, concreción y sencillez de las cláusulas, por una parte, y que no sean ilegibles, ambiguas, oscuras o incomprensibles, por otra, sino que el consumidor pueda efectuar una previsión sobre el costo real de la operación, para lo cual el banco debió desplegar una amplia labor informativa. Dicha información ha de permitir al prestatario identificar que el mecanismo de la variabilidad del tipo puede convertirlo en un interés fijo mínimo, y representarse subjetivamente una relación de equilibrio prestacional entre precio y coste del préstamo, se- 
gún las circunstancias concurrentes al momento de contratarlo. En consecuencia, el TS aparta la reciprocidad contractual como criterio para valorar la posible abusividad de las cláusulas suelo y, en íntima conexión con ello, ratifica la prohibición de enjuiciar los precios en los contratos celebrados entre consumidores y empresarios.

3. ${ }^{a}$ A la nulidad parcial del préstamo, es decir, de la cláusula suelo, por vulneración de la transparencia informativa, responde el TS limitando temporal y materialmente los efectos «ex tunc» inherentes a la nulidad contractual. Para tal fin se ha dispuesto una calculada mezcla de argumentos relativos a la ineficacia contractual según el tipo de acción ejercitada y a los efectos materiales de la cosa juzgada (art. $222.3 \mathrm{LEC}^{76}$. A mi parecer ello se debe a que nuestro TS desea (lo ha expresado claramente en más de una ocasión) que la presunta abusividad de las cláusulas suelo sea debatida en sede judicial para que "puedan valorarse las infinitas circunstancias y contextos a tener en cuenta», lo cual no deja de ser una incongruencia más si se ha dado por probado que la cláusula suelo constituye una condición general de la contratación. Se desea evitar un automatismo conducente a apreciaciones erróneas en la invocación de su doctrina por parte de los consumidores y, de paso, se ponen más trabas a la operatividad del mecanismo ejecutivo previsto en el artículo 519 LEC, referido a la acción ejecutiva de consumidores y usuarios fundada en sentencia de condena sin determinación individual de los beneficiados.

4. ${ }^{\text {a }}$ Con todo, fuera por la falta de reciprocidad no estimada, sea por la falta de transparencia constituida, en la conciencia social, quién puede dudarlo, el resultado propiciado ha sido el efecto prohibido y que se trataba de evitar, la revisión del precio de los préstamos hipotecarios con cláusulas suelo no transparentes.

\section{POST SCRIPTUM}

$\mathrm{Al}$ escribir estas líneas debemos hacernos eco de varios acontecimientos que han tenido gran repercusión en la cuestión:

1. La corrección impuesta al Tribunal Supremo por el TJUE en su sentencia de 21 de diciembre de 2016 en cuanto a los efectos de cláusulas nulas. Declarada la nulidad de una cláusula suelo por abusiva,

${ }^{76}$ El artículo 222.3 LEC establece: «La cosa juzgada afectará a las partes del proceso en que se dicte y a sus herederos y causahabientes, así como a los sujetos, no litigantes, titulares de los derechos que fundamenten la legitimación de las partes conforme a lo previsto en el artículo 11 de esta Ley». 
las entidades bancarias deberán devolver dinero desde este día hasta el mismo momento de la suscripción del préstamo que la contiene, pues no existe otra forma de restablecer la situación de hecho y de Derecho en que se encontraría el consumidor si la cláusula no hubiera existido. Otra cosa será, y en ésta se centrará ahora la tensión entre las partes, lo que proceda devolver, lo que la entidad bancaria esté dispuesta a entregar al cliente y lo que éste desee aceptar a fin de evitar nuevas contiendas judiciales.

2. Con la publicación del Real Decreto Ley 1/2007, de 20 de enero, de medidas urgentes de protección de consumidores en materia de cláusulas suelo (BOE núm. 18, de 21 de enero) ${ }^{77}$ persigue el legislador evitar el aumento de la litigiosidad a consecuencia de la citada sentencia del TJUE. Para ello ha regulado tan sólo unos trámites voluntarios siguiendo un criterio de intervención mínima (II). La norma introduce un nuevo compás en el que los prestatarios esperan -ojalá no quede en vana ilusión - una postura más conciliadora por parte de las entidades bancarias que la exhibida hasta el momento.

3. Con el mismo fin preventivo, la Comisión Permanente del Consejo General del Poder Judicial anunció el 9 de febrero de 2017 la aprobación de una propuesta de plan de urgencia para hacer frente al previsible aumento de litigios sobre cláusulas suelo como consecuencia de la referida sentencia. En mi opinión no es extraña la masiva judicialización que hoy ofrece el problema. Sólo quedaba un tema pendiente de solución, a saber, si la doctrina sobre la irretroactividad del TS sería mantenida o corregida por el TJUE, pues a partir de éste momento los consumidores podrían valorar definitivamente cuánto sería el interés económico que les alentaría a demandar en su caso a las entidades bancarias.

4. En la doctrina científica se hacen esfuerzos por avanzar en la construcción de la transparencia en el concreto ámbito de la contratación bancaria ${ }^{78}$.

Por último, hay que anotar al menos dos problemas destacados en el actual estado de la cuestión. Uno, el relativo a la cosa juzgada, cuya apreciación en términos opuestos por prestatarios y entidades bancarias, llevaría al traste cualquier acercamiento de posturas. El

${ }^{77}$ Convalidado según la Resolución de 31 de enero de 2017, del Congreso de los Diputados (BOE núm. 32, de 7 de febrero).

${ }^{78}$ Vid. ORduña Moreno, F. J., y otros, Control de transparencia y contratación bancaria. Régimen jurídico y doctrina jurisprudencial aplicable. Ed. Tirant lo Blanch, Valencia, 2016. 
otro, de matices ya visibles en el foro, cabría residenciarse en el nuevo plazo de prescripción de cinco años para las acciones personales que no tengan plazo especial, establecido en el artículo 1964 CC, tras ser modificado el precepto por la Disposición Final Primera de la Ley 42/2015 de reforma de la LEC. 